\title{
CLARIFICATION OF FINGER MILLET (Eleusine coracana $L$.) JAND USING FINING AGENTS
}

\author{
D.B. Karki ${ }^{*}$ \\ G.P. Kharel
}

\section{ABSTRACT}

Finger millet (Eleusine coracana L.) was fermented using a defined fermentation starter to prepare millet jand (a traditional cereal-based alcoholic beverage). Millet jand was clarified using bentonite, gelatin and tannin and the effect of bentonite on sensory and chemical characteristics were evaluated. Effects of holding time, temperature and jand acidity on clarification were also studied.

Addition of bentonite at the rate of $3 \mathrm{~g} / \mathrm{L}$ resulted in the best clarification without significantly affecting $(p>0.05)$ the chemical and organoleptic properties of the clarified jand, whereas tannin and tannin-gelatin combination showed a negative effect on clarification. Jand acidity and bentonite concentration had a significant effect $(p<0.05)$ on clarification. Bentonite, when added to pasteurized and gravity settled jand, showed an adverse effect on clarification. Holding of bentonite treated jand beyond 3 days at room temperature $\left(29 \pm 1{ }^{\circ} \mathrm{C}\right)$ did not improve clarification. Similarly, holding of bentonite treated sample under refrigeration $\left(5 \pm 1^{\circ} \mathrm{C}\right)$ did not improve clarity compared to room temperature held sample. It was concluded that bentonite could be a promising fining agent in the clarification of millet jand without sacrificing quality.

Key words: finger millet jand, clarification, fining agents, chemical and sensory characteristics.

\section{INTRODUCTION}

In Nepal, the term Jand is a generic name for all cereal-based alcoholic beverages; Tibetan call it 'minchha chhyaanh' and the Lepcha call it 'mong chee' (Thapa and Tamang, 2004). Finger millet is the most preferred substrate for jand preparation and is considered to yield an unmatched quality product. The basic reason behind it is the uniqueness in flavor and taste of the product. Finger millet seeds are sometimes supplemented with a small amount of wheat or corn or rice singly or in combination. The fermented cereal when squeezed out with added water and strained through strainer yields an extract called 'jand'. Technically, it is a traditional undistilled alcoholic beverage prepared by solid-state fermentation of starchy cereals. The fermentation is initiated by a mixed culture called murcha consisting of yeasts, molds and lactic acid bacteria. (Karki, 1986).

Fermented cereals are served in various forms, the most popular being strained jand (cloudy-white aqueous extract) and may be served in deep bowls. Toongba is a variation of the serving procedure of the fermented mash of cereals.

* Dr. Karki is a Professor at Central Campus of Technology, Dharan-14, Hattisar, Sunsari, Nepal. 
Mash is kept in wooden or aluminum cylindrical vessel and warm water poured over it. The soluble material slowly gets leached out in the vessel. A bamboo tube or other suitable straw is inserted in it and the extract is sucked in until the extract is no more palatably juicy (Rai, 1991; KC and Thapa, 2005). Jand finds a very prominent place in Limbu and Rai culture in particular and among other ethnic groups in general. The tradition of offering jand to guests is a unique way of showing hospitality. It is also used in several festive occasions, ritual rites, settling disputes and appeasing deities (Rai, 1991).

The major set-back in the commercialization of jand is the lack of research and development on it. The existing method of cereal fermentation has several drawbacks, viz., use of traditionally prepared fermentation starter, poor sanitary conditions, uncontrolled processing, that lead to a poor and inconsistent quality product. Strained jand has a very short shelf-life, normally of the order of 2-3 hr after it has been strained (Mongar and Rai, 2005). Although jand can be preserved by pasteurization, the bottled product is unsightly owing to the settling of solids in the bottle during storage. This could be a potential area of research in the improvement of sensory quality of jand.

Fining is the addition of reactive or adsorptive substances to remove or reduce the concentration of one or more undesirable constituents (Zoecklein et al., 1997). Fining agents are widely used to clarify fruit and vegetable juices, wines and other liquid but their use in the clarification of jands has not been found so far. There are many indigenous food fermentations in the world and some of them such as Japanese sake, Nigerian ogi and African kaffir beer have been intensively studied to determine the optimum conditions for fermentation, the essential micro flora involved, the biochemical, nutritional and flavor changes that occur and the possible toxicological problems that can arise (Steinkraus, 1983).

In Nepalese context, little work has been done in the past regarding the fermentation of cereals using murcha (Rai, 1991; Subba, 1985; Das, 2004); preparation and utilization of defined starter for cereal fermentation (Verma, 1991; Shrestha, 2003) and preservation of strained jand using pasteurization (Mongar and Rai, 2005). However, much attention has not been paid towards its development in the past and consequently the art of jand making has been limited to home-brewing only. Time has now come that we have to commercialize our culturally and socially accepted traditional fermented product by quality enhancement through process refinement. It is anticipated that clarification in conjunction with pasteurization could improve the aesthetic quality, storage stability and marketability of the clarified millet jand. Hence, the present work was conducted aimed at searching for the best fining agents and optimizing clarification conditions in order to produce clarified millet jand, as a beer analogue.

\section{MATERIALS AND METHODS}

\section{Preparation OF MiLlet JAND}

Dehusked millet was cooked, cooled in an aluminum tray and mixed with defined fermentation starter at the rate of $10 \mathrm{~g} / \mathrm{kg}$ of uncooked millet. The 
try was covered with moistened muslin cloth in order to prevent drying of the mass and kept for $48 \mathrm{~h}$ at room temperature $\left(29^{\circ} \pm 1^{\circ} \mathrm{C}\right)$ for biomass development. The biomass developed mass was filled into plastic container, closed and kept for alcoholic fermentation for 15 days at room temperature. The fermented millet was mixed with water ( 1 part millet +1.5 parts water, $\mathrm{m} / \mathrm{v})$, stirred gently and allowed to stand for $30 \mathrm{~min}$ after which the extract was strained through plastic net to obtain finger millet jand.

\section{CLARIFICATION OF MILLET JAND USING FINING AGENTS}

\section{Selection of fining agents}

Different fining agents, viz., bentonite, gelatin, tannin and tannin-gelatin were tried for the clarification of millet jand. Bentonite was added at concentrations of $0,1,2,3$ and $4 \mathrm{~g} / \mathrm{L}$ whereas for gelatin, tannin and tannin-gelatin combination, the finings were used at concentrations of $0,0.1,0.2,0.3$ and $0.4 \mathrm{~g} / \mathrm{L}$ in each case. Bentonite and tannin were used as $5 \%(\mathrm{~m} / \mathrm{v})$ solution in distilled water and $1 \%(\mathrm{~m} / \mathrm{v})$ solution in $50 \%(\mathrm{v} / \mathrm{v})$ ethanol respectively. In the case of gelatin, $1 \mathrm{~g}$ of gelatin was mixed with $75 \mathrm{ml}$ of distilled water, warmed until dissolved and the final volume was made up to $100 \mathrm{ml}$ with distilled water after the addition of $0.5 \mathrm{~g}$ of citric acid and 0.1 $\mathrm{g}$ sodium benzoate (as preservative).

A measured volume $(100 \mathrm{~mL})$ of millet jand was taken in several $250 \mathrm{ml}$ conical flasks and fining agents were added to each flask at different concentrations and mixed. The flasks were heated rapidly to raise the temperature of the jand to $70{ }^{\circ} \mathrm{C}$, the mouth of the flasks were corked and placed in a water bath maintained at $70{ }^{\circ} \mathrm{C}$ for 10 min followed by immediate cooling to room temperature using ice-water bath. The flasks were kept for $24 \mathrm{~h}$ at room temperature and the turbidity of the supernatant was measured. The ones showing minimum turbidity (i.e. greater brilliancy) at the lowest concentration of fining agents were chosen. For tannin-gelatin combination treatment, tannin was added first, mixed for sometime followed by gelatin addition in equal amount.

Effect of bentonite concentration and jand acidity; holding time and clarification temperature on the clarification of millet $j$ and

In order to study the effect of bentonite concentration and jand acidity, four levels of bentonite concentration $(0,1,2$ and $3 \mathrm{~g} / \mathrm{L})$ and three levels of acidity $(0.35,0.45$ and $0.55 \%$ as lactic acid) were used. The required acidity levels were adjusted by using $10 \%(\mathrm{~m} / \mathrm{v})$ lactic acid solution or $1 \mathrm{~N} \mathrm{NaOH}$ solution as required. Clarification of millet jand was done using different treatment combinations as described earlier and the turbidities of the clarified jands were determined.

In order to study the effect of holding time, bentonite treated $(3 \mathrm{~g} / \mathrm{L})$ and pasteurized millet jand samples were kept at room temperature $\left(29 \pm 1{ }^{\circ} \mathrm{C}\right)$ and the turbidities of supernatants were measured every day for 4 days. Similarly, two levels of bentonite concentration ( 0 and $3 \mathrm{~g} / \mathrm{L})$ and two levels of temperature (room temperature and refrigerated temperature, $5 \pm 1^{\circ} \mathrm{C}$ ) were used to study the effect of 
bentonite concentration and holding temperature. The treated samples were held at both temperatures for $24 \mathrm{~h}$ and turbidities of the supernatants were measured.

\section{Effect of sequence of bentonite addition on clarification}

The acidity of millet jand was adjusted to $0.4 \%$ as lactic acid and it was divided into three lots. The first lot was pasteurized without bentonite treatment (control) the second lot was pasteurized with bentonite $(3 \mathrm{~g} / \mathrm{L})$ and the third lot was pasteurized, gravity settled for overnight and to the supernatant bentonite was added at the rate of $3 \mathrm{~g} / \mathrm{L}$. All the samples were kept for $24 \mathrm{~h}$ at room temperature and the turbidities of the supernatants were recorded.

Effect of bentonite treatment on the chemical and sensory quality of clarified jand.

The chemical characteristics and organoleptic quality in terms clarity, color, taste and smell of both the bentonite treated $(3 \mathrm{~g} / \mathrm{L})$ and untreated (control) samples were analyzed.

\section{ANALYTICAL PROCEDURE}

The turbidity was determined by using turbidity meter, LP 2000 (Hanna Instrument, Italy) and the results were expressed as FTU (Formazine Turbidity Unit). TSS was measured using portable refractometer (Hanna Instrument, Portugal). Total, fixed and volatile acidities and total ester contents (as g ethyl acetate/L alcohol) were determined as per Kirk and Sawyer (1991). pH was determined using $\mathrm{pH}$ meter (Hanna Instrument, Portugal). Conductivity was determined using conductivity meter, HI 8033 (Hanna Instrument, Portugal). Alcohol content was determined by visible spectrometric dichromate oxidation method as per Zoecklein et al. (1997). Reducing sugar, sucrose and total sugar contents were determined by Lane and Eynon method as per Ranganna (1986). Glucose content was determined by glucose oxidase method using glucose oxidase peroxidase reagent (Span Diagnostics Ltd., India) as per Sadasivam and Manickam (1996). Water soluble protein was determined by Lowry's method as per Sadasivam and Manickam (1996) and the amount of protein was calculated using a bovine albumin (Central Drug House, Pvt. Ltd., England) standard curve. Total nitrogen (micro-kjeldahl method) and non-protein nitrogen contents were determined as per Sadasivam and Manickam (1996).

Total solid content was determined by drying $25 \mathrm{ml}$ of the sample in a hot air oven at $100^{\circ} \pm 5^{\circ} \mathrm{C}$. Insoluble solid was determined by drying the residue obtained after filtration of $25 \mathrm{ml}$ of sample through Whatman No 40 filter paper in a hot air oven at $100^{\circ} \pm 5^{\circ} \mathrm{C}$. Starch content was determined by acid hydrolysis method as per Ranganna (1986). Total phenolic content was determined as per Sadasivam and Manickam (1996) with minor changes. Color development was carried out by incubating treated sample at room temperature for $2 \mathrm{~h}$ and the resulting blue color was recorded in a digital spectrophotometer, Model 305 (M.S. Electronics Pvt. Ltd., India) at $760 \mathrm{~nm}$. The concentration of phenolic was found out using a standard curve prepared from gallic acid (s.d. fine-chem Ltd., 
Mumbai, India) and the result was expressed as gallic acid equivalent (GAE). Tannin content was determined by Folin-Denis method as per Ranganna (1986). The tannin content was calculated from a standard graph of tannic acid (Merck Pvt. Ltd., Mumbai, India) and the result was expressed as equivalent. Antioxidant activity was determined by DPPH method using $0.5 \mathrm{ml}$ of diluted (1 to $10 \mathrm{ml})$ and filtered sample (Whatman No. 40) and $3 \mathrm{ml}$ of $0.003 \%$ DPPH in methanol as per Zhao et al. (2010). Fusel oil content was determined by spectrophotometric method as per AOAC Official Method 959.05 (2005) and the result was expressed as $\mathrm{g} / \mathrm{L}$ alcohol. Methanol content was determined by chromotropic acid colorimetric method as per AOAC Official method 958.04 (2005). Total, free and combined aldehydes contents were determined by titrimetric method as per AOAC Official Method 972.08 (2005) and the results were expressed as $g$ acetaldehyde/L alcohol.

Sensory evaluation of the unclarified and clarified jand was carried out by using hedonic rating test as per Ranganna (1986). Nine semi-trained panelists consisting of administrative staffs, faculties and students of the college were asked to rate the acceptability of the product on a 9- point scale ranging from 1 ('dislike extremely') to 9 ('like extremely').

\section{STATISTICAL ANALYSIS}

The experiment was conducted in a RCBD with three replications. Data were analyzed using one-way and two-way ANOVA using Genstat 5 Release 3.2 (1995) at 5\% level of significance. Treatment means were compared using LSD and t-test as required.

\section{RESULTS AND DISCUSSION}

\section{SELECTION OF FINING AGENTS}

Effects of different fining agents on the clarification of millet jand are shown in Fig. 1 and 2. Turbidity of the clarified jand decreased with increasing concentration of both bentonite and gelatin. Bentonite greatly reduced turbidity compared to gelatin. But both tannin and tannin-gelatin combination treatments increased turbidity with increasing concentration. Statistically, bentonite treatment showed a significant effect $(\mathrm{p}<0.05)$ on the clarification of millet jand. The mean turbidity values were 143, 131, 82, 62 and 48.33 FTUs for 0, 1, 2, 3, and $4 \mathrm{~g} / \mathrm{L}$ bentonite respectively and the values were significantly different from each other by LSD.

Ough and Amerine (1960) reported that $12.5 \mathrm{lbs}$ of bentonite per 1000 gallons (about 1.5 of bentonite per litre) of must increased clarity and filter speed and lightened the color of new wines. According to Weger (1965), bentonite can be used as needed in Italy, but German law limits it to $1.5 \mathrm{~g} / \mathrm{L}$ and Austria to $2 \mathrm{~g} / \mathrm{L}$. 
Fig. 1: Effect of bentonite concentration on the clarification of millet jand. Values are the means of three determinations \pm SD.

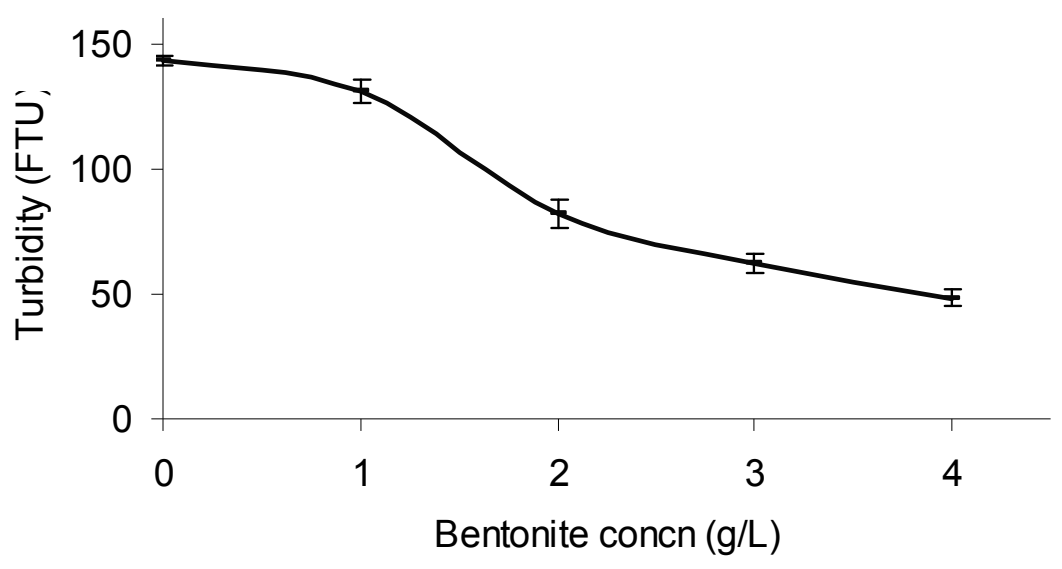

Fig. 2: Effect of tannin, gelatine and tannin-gelatine treatments on the clarification of millet jand.

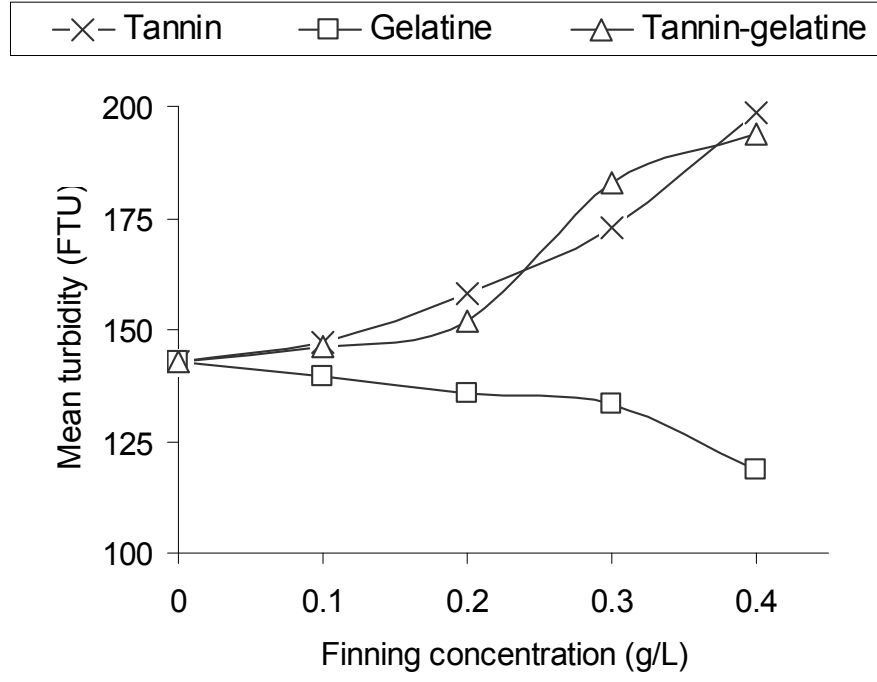


For new cloudy dissert wines, the bentonite dose is usually $0.36-0.72$ $\mathrm{g} / \mathrm{L}$. For well settled, fairly clear dessert wines about $0.36-0.60 \mathrm{~g} / \mathrm{L}$ is often sufficient. Some wine makers warm dessert wines to about $100^{\circ} \mathrm{F}$ before adding the bentonite (Amerine et al., 1967). According to Zeocklein et al. (1997) addition of bentonite to red wines at levels of $0.06-0.12 \mathrm{~g} / \mathrm{L}$ improves membrane filterability due to reduction in colloidal suspended particles.

\section{EFFECT OF BENTONITE CONCENTRATION AND ACIDITY ON THE CLARIFICATION OF MILLET JAND.}

Bentonite concentrations of $0,1,2$ and $3 \mathrm{~g} / \mathrm{L}$ and acidity levels of 0.35 , 0.45 and $0.55 \%$ as lactic acid were used to study the effect of bentonite concentration and acidity and the results are shown in Fig. 3.

Bentonite concentrations, acidity and bentonite-acidity interaction all showed significant effect $(\mathrm{p}<0.05)$ on millet jand clarification. Increasing bentonite concentrations for any levels of acidity remarkably decreased the turbidity. Increasing acidity from 0.35 to $0.45 \%$ significantly reduced turbidity at all levels of bentonite while further increase in acidity substantially increased turbidity irrespective of bentonite concentrations. Maximum reduction in turbidity was observed at $0.45 \%$ acidity and $3 \mathrm{~g} / \mathrm{L}$ of bentonite of all the treatments use.

Fig. 3: Effect of bentonite concentration and jand acidity on the clarification of millet jand.

$$
\multimap 0.35 \% \rightarrow-0.45 \% \multimap 0.55 \%
$$

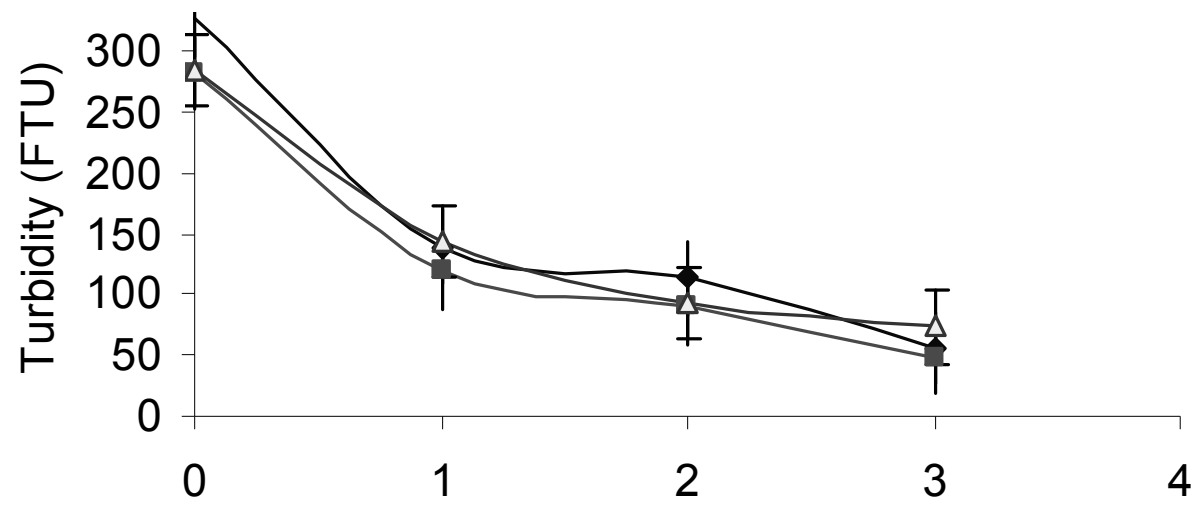

Bentonite concentration $(\mathrm{g} / \mathrm{L})$ 


\section{EFFECT OF HOLDING TEMPERATURE, TIME AND SEQUENCE OF BENTONITE} ADDITION ON THE CLARIFICATION OF MILLET JAND

The effect of holding temperature on the turbidity of millet jand treated with 0 and $3 \mathrm{~g} / \mathrm{L}$ bentonite and held for $24 \mathrm{~h}$ at room temperature $\left(29 \pm 1^{\circ} \mathrm{C}\right)$ and at refrigerated temperature $\left(5 \pm 1^{\circ} \mathrm{C}\right)$ is shown in Fig. 4. The effect of bentonite treatment was significant while those of temperature and bentonite-temperature interaction were insignificant $(\mathrm{p}>0.05)$. The turbidity of control samples held at room and refrigerated temperature were 314 and 317.6 FTUs respectively, however the values were not significantly different. Similarly, the values for 3 $\mathrm{g} / \mathrm{L}$ bentonite treated samples held at room and refrigerated temperature were 61 and 59.1 FTUs respectively and the values were not statistically different. From Fig. 4 it can be envisaged that bentonite treatment significantly reduced turbidity at both holding temperatures while reducing holding temperature from room to refrigeration temperature did not improve clarification.

Fig. 4: Effect of bentonite concentration and holding temperature on the clarification*

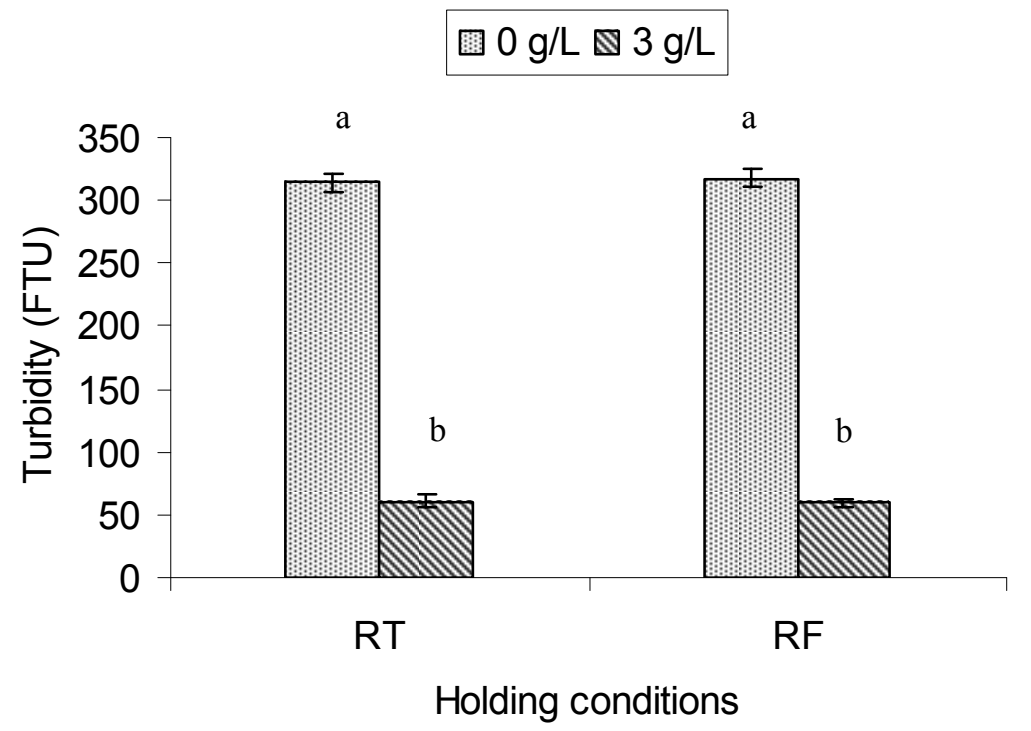

* Values are the means of three determinations \pm SD. Bars with different letters are significantly different $(\mathrm{p}<0.05)$.

RT: room temperature $\left(29 \pm 1^{\circ} \mathrm{C}\right)$ and $\mathrm{RF}$ : refrigerated temperature $\left(5 \pm 1^{\circ} \mathrm{C}\right)$ 
Effect of holding time on clarification is shown in Fig. 5. The mean turbidity values for first, second, third and fourth day held millet jands were 60.3, 55.87, 51.45 and 49.9 FTUs respectively. Statistically analysis revealed that holding time had a significant effect $(\mathrm{p}<0.05)$ on turbidity and it decreased with time up to the third day and then remained statistically unchanged. It was found that bentonite treatment of $3 \mathrm{~g} / \mathrm{L}$ during pasteurization and a holding time of 3 days at room temperature were sufficient to clarify the millet jand.

Fig. 5: Effect of holding time on the clarification of millet jand. .*

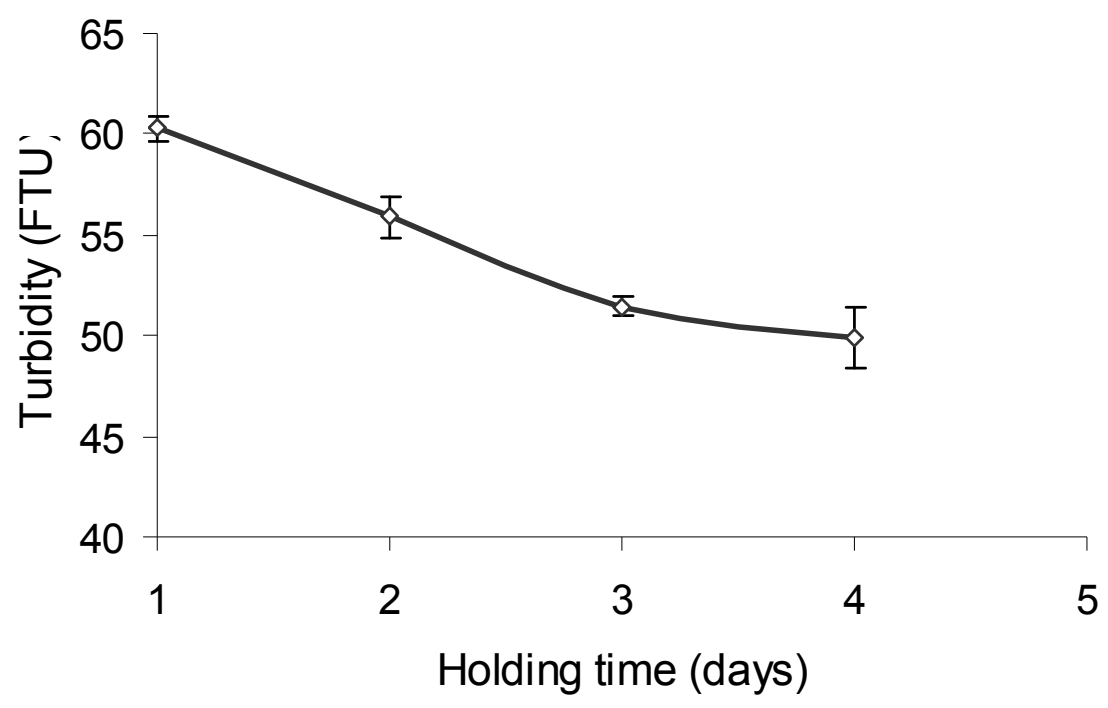

$*$ : Values are the means of three determinations \pm SD 
Fig. 6: Effect of sequence of bentonite addition on the clarification of millet jand*

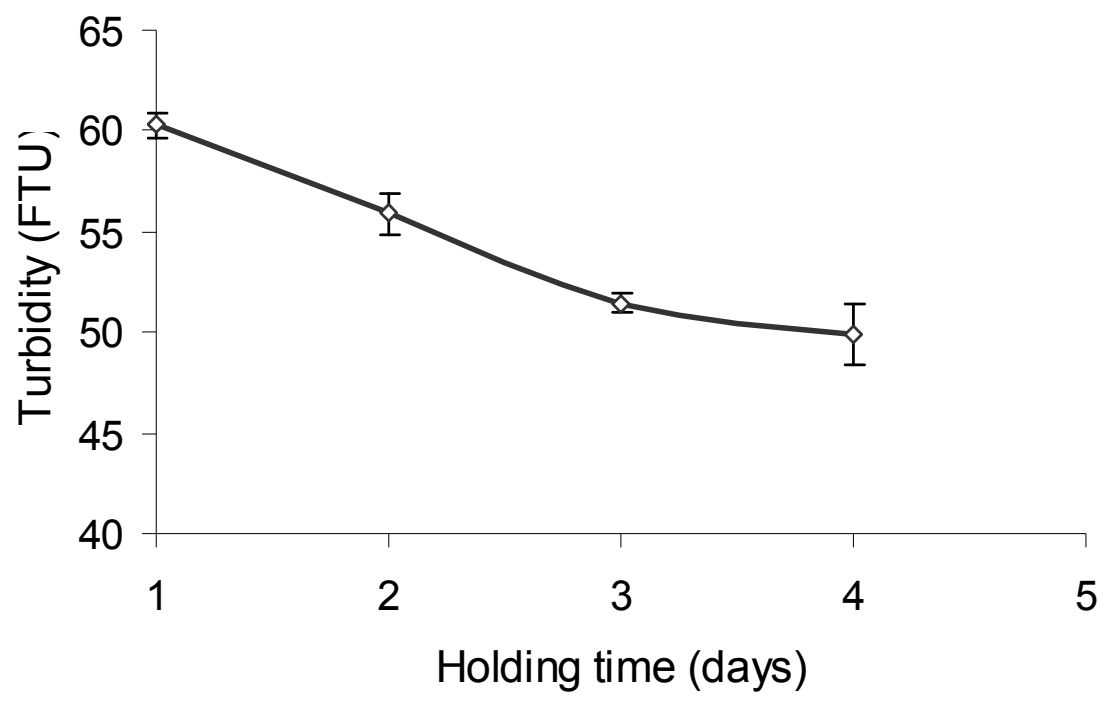

* Values are the means of three determinations \pm SD.

Control: Pasteurization only

DP: Bentonite treatment followed by pasteurization

PSB: Bentonite treatment in pasteurized and gravity settled jand

The turbidities of the supernatants obtained by pasteurization only (control) bentonite treatment during pasteurization and bentonite treatment in pasterurized and gravity settled clear jands were measured and the results are shown in Fig. 6. Bentonite treatment had a significant effect on the clarification of millet jand. The mean turbidity values for control, bentonite treated ( $3 \mathrm{~g} / \mathrm{L})$ followed by pasteurization and bentonite treatment in pasteurized and gravity settled samples were 319.33, 61 and 109.7 FTUs respectively. Statistically, the values were significantly different from each other. It was found that addition of bentonite during pasteurization considerably improved the clarity while bentonite treatment to pasteurized and gravity settled jand failed to improve clarity.

\section{EFFECT OF BENTONITE TREATMENT ON CHEMICAL AND SENSORY CHARACTERISTICS OF MILLET JAND.}

Effect of bentonite treatment on chemical characteristics of millet jand is shown in Table 1. Total soluble solids, $\mathrm{pH}$ and volatile acidity were not affected while total acidity and fixed acidities were significantly decreased by clarification. Reducing sugar, sucrose, total sugar and glucose contents were lower in clarified jand compared to unclarified one. Similarly, bentonite treatment significantly reduced the total nitrogen, non-protein nitrogen, total solids and 
insoluble solid contents in clarified jand than that of control (untreated) one. Starch content was $1.31 \% \mathrm{~m} / \mathrm{v}$ in unclarified jand while it was nil in the clarified jand. Total phenolics, tannin, antioxidant activity and electrical conductivity were not affected by clarification. Alcohol, methanol and total ester contents were lower in clarified jand while fusel oil content remained unchanged. A significant reduction in total, free and combined aldehydes contents occurred by bentonite treatments.

Effects of bentonite treatment on organoleptic quality of clarified millet jand is shown in Fig. 7 The mean sensory scores for color, clarity, taste and smell were found to be 7.43 and 7.86; 6.86 and 8.29; 7.86 and 7.71 and 8.29 and 8.29 for control and bentonite treated samples respectively. Except clarity, all other sensory attributes were not different between control and bentonite treated samples. Clarity was significantly improved as well as taste, smell, and color were also not affected by bentonite treatment. According to Amerine et al. (1967), when properly used, bentonite has little or no effect on the flavor and bouquet of table or dessert wines, which also supports our findings.

Fig. 7: Effect of bentonite treatment on the sensory quality of clarified jand.*

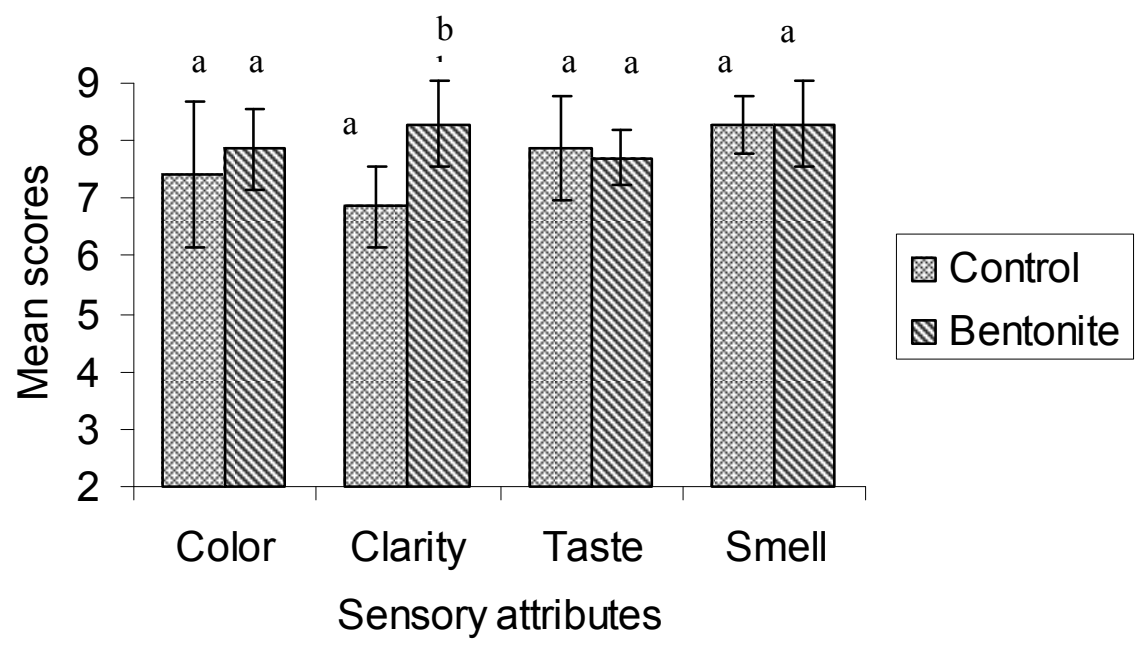

* Values are the means of three determinations \pm SD. Bars having different letters for any attribute are significantly different $(\mathrm{p}<0.05)$.

\section{CONCLUSIONS}

Millet jand containing $0.35 \%(\mathrm{~m} / \mathrm{v})$ total acidity (as lactic acid) treated with $3 \mathrm{~g} / \mathrm{L}$ of bentonite during pasteurization and held for 3 days at room temperature $\left(29 \pm 1^{\circ} \mathrm{C}\right)$ resulted the best clarification of all the treatments used. Bentonite treatment significantly improved clarity without affecting color, taste and smell of the clarified jand compared to control (untreated sample). Although 
some of the chemical characteristics of unclarified jand were significantly reduced by clarification, but they were not of considerable extent as to adversely affect the organoleptic quality of the clarified jand. Hence, bentonite treatment could be a promising means of improving clarity and thereby enhancing aesthetic quality and storage stability of finger millet jand.

\section{WORKS CITED}

Amerine, M.A., Berg, H.M and Cruess, W.V. (1967). The Technology of Wine Making, $2^{\text {nd }}$ Edn. The AVI Publishing Co. Inc., Westport, Connecticut, p. 162.

AOAC (2005). Official Methods of Analysis of AOAC International, $18^{\text {th }}$ edn. AOAC International, Suite 500, USA.

Das, D.K. (2004). Improvement in traditional method of preparing jand from finger millet. B.Tech (Food) Dissertation, Central Campus of Technology, Dharan, Nepal.

Karki, T.B. (1986). Murcha. In: A Concise Handbook of Indigenous Fermented Foods in the ASCA Countries (S. Saono, R. Hull and D. Dhamcharee, eds.). The Government of of Australia, Canberra, $\mathrm{p} 136$.

K.C. J.B. and Thapa, T.B. (2005). Fermented foods of Nepal. A brief review. J. Food Sci. and Technol., Nepal. 1(1): 25- 28.

Kirk, R.S. and Sawyer, R. (1991). Pearson's Composition and Analysis of Foods, $9^{\text {th }}$ Edn. Addison Wesley Longman Ltd., Edinburgh Gate, Harlow, England.

Mongar, G and Rai, B.K. (2005). Preservation of strained jand by pasteurization. J. Food Sci. and Technol., Nepal. 1 (1): 58-61.

Ough, C.S. and Amerine, M.A. (1960). Experiments with controlled fermentation. IV. Am. J. Enol. Vitic, 11: 5- 14.

Rai, B.K. (1991). Preparation and quality evaluation of jand from malted and unmalted millet (kodo) using A. oryzae and S. sake. B. Tech (Food) Dissertation. Central Campus of Technology, Dharan, Nepal.

Ranganna, S. (1986). Handbook of Analysis and Quality Control of Fruits and Vegetable Products, $2^{\text {nd }}$ Edn. Tata McGraw-Hill Publishing Company, Ltd., New Delhi, India.

Sadasivam, S and Manickam, A. (1996). Biochemical Methods, $2^{\text {nd }}$ edn. New age International (P) Limited, New Delhi, India.

Shrestha, H. and Rati, E. (2003). Defined microbial starter formulation for the production of poko - a traditional fermented food product of Nepal. Food Biotechnology. 17(1): 15-23.

Steinkraus, K.H. (1983). Handbook of Indigenous Fermented Foods. Marcel Dekker Inc., New York. 
Subba, C. (1985). Rakshi production from finger millet (koda) by traditional method. B. Tech (Food) Dissertation. Central Campus of Technology, Dharan, Nepal.

Thapa, S. and Tamang, J.P. (2005). Porduct characterization of kodo ko jaanr: fermented finger millet beverage of Himalays. Food Microbiology, 21: 617-622.

Verma, S.K. (1991). Study on the preparation and efficiency of starter cake from $A$. oryzae and $S$. sake using rice as a binder. B. Tech (Food) Dissertation. Central Campus of Technology, Dharan, Nepal.

Weger, B. (1965). Calcium and Natrium bentonite. Wein-Wissen, 20: 545-559. In: Zoecklein, B.W., Fugelsang, K.C., Gump, B.H. and Nury, F.S. (1997). Wine Analysis and Production. CBS Publishers and Distributors, New Delhi, India.

Zhao, H., Chen, W., Lu, L. and Zhao, M. (2010). Phenolic profiles and antioxidant activities of commercial beers. Food Chem., 119(3): 11501158.

Zoecklein, B.W., Fugelsang, K.C., Gump, B.H. and Nury, F.S. 91997). Wine Analysis and Production. CBS Publishers and Distributors, New Delhi, India. 
Table 1: Effect of bentonite treatment on the chemical characteristics of finger millet jand

\begin{tabular}{|c|c|c|}
\hline \multirow[t]{2}{*}{ Parameters } & \multicolumn{2}{|c|}{ Values* } \\
\hline & Unclarified & Clarified \\
\hline 1. $\mathrm{TSS}^{\mathrm{o}} \mathrm{Bx}$. & $4.97^{\mathrm{a}}(0.06)$ & $4.97^{\mathrm{a}}(0.06)$ \\
\hline 2. $\mathrm{pH}$ & $4.38^{\mathrm{a}}(0.03)$ & $4.38^{\mathrm{a}}(0.03)$ \\
\hline \multicolumn{3}{|l|}{ 3. Acidities } \\
\hline a. Total as lactic, $\% \mathrm{~m} / \mathrm{v}$ & $0.34^{\mathrm{a}}(0.006)$ & $0.31^{\mathrm{b}}(0.003)$ \\
\hline b. Fixed as lactic, $\% \mathrm{~m} / \mathrm{v}$ & $0.29^{\mathrm{a}}(0.01)$ & $0.27^{\mathrm{b}}(0.01)$ \\
\hline c. Volatile as acetic, $\% \mathrm{~m} / \mathrm{v}$ & $0.0290^{\mathrm{a}}(0.0035)$ & $0.0297^{\mathrm{a}}(0.0006)$ \\
\hline 6. Reducing sugar as dextrose, $\% \mathrm{~m} / \mathrm{v}$ & $1.37^{\mathrm{a}}(0.01)$ & $1.32^{\mathrm{b}}(0.01)$ \\
\hline 7. Sucrose, $\% \mathrm{~m} / \mathrm{v}$ & $0.31^{\mathrm{a}}(0.01)$ & $0.28^{\mathrm{b}}(0.01)$ \\
\hline 8. Total sugar, $\% \mathrm{~m} / \mathrm{v}$ & $1.68^{\mathrm{a}}(0.01)$ & $1.57^{\mathrm{b}}(0.06)$ \\
\hline 9. Glucose, $\mathrm{mg} / 100 \mathrm{ml}$ & $38.9^{\mathrm{a}}(1.65)$ & $44.4^{\mathrm{b}}(1.22)$ \\
\hline 10. Water soluble protein, $\mathrm{mg} / 100 \mathrm{ml}$ & $301.3^{\mathrm{a}}(31.5)$ & $288.1^{\mathrm{a}}(22.0)$ \\
\hline 11. Total nitrogen, $\% \mathrm{~m} / \mathrm{v}$ & $0.06^{\mathrm{a}}(0.0002)$ & $0.04^{\mathrm{b}}(0.0016)$ \\
\hline 12. Non-protein nitrogen, $\mathrm{mg} / 100 \mathrm{ml}$ & $4.93^{\mathrm{a}}(0.11)$ & $4.11^{\mathrm{b}}(0.09)$ \\
\hline 13. Total solids, $\% \mathrm{~m} / \mathrm{v}$ & $3.17^{\mathrm{a}}(0.11)$ & $2.40^{\mathrm{b}}(0.05)$ \\
\hline 14. Insoluble solids, $\% \mathrm{~m} / \mathrm{v}$ & $1.27^{\mathrm{a}}(0.03)$ & $0.22^{b}(0.02)$ \\
\hline 15. Starch, $\% \mathrm{~m} / \mathrm{v}$ & $1.31^{\mathrm{a}}(0.32)$ & $0.00^{\mathrm{b}}(0.00)$ \\
\hline 16. Total phenolics as GAE, $\mathrm{mg} \%$ & $22.37^{\mathrm{a}}(0.12)$ & $22.80^{\mathrm{a}}(0.52)$ \\
\hline 17. Tannin as tannic acid, mg $\%$ & $20.33^{\mathrm{a}}(0.49$ & $19.93^{\mathrm{a}}(0.06)$ \\
\hline 18. Antioxidant activity, $\%$ & $68.59^{\mathrm{a}}(4.24)$ & $75.41^{\mathrm{a}}(3.88)$ \\
\hline 19. Electrical conductivity, $\mu \mathrm{S} / \mathrm{cm}$ & $14.6^{\mathrm{a}}(0.01)$ & $1.46^{\mathrm{a}}(0.01)$ \\
\hline 20. Alcohol, \% v/v & $7.90^{\mathrm{a}}(0.01)$ & $6.93^{\mathrm{b}}(0.06)$ \\
\hline 21. Fusel oil, g/L alcohol & $5.061^{\mathrm{a}}(0.002)$ & $5.120^{\mathrm{a}}(0.117)$ \\
\hline 22. Methanol, g/L alcohol & $2.511^{\mathrm{a}}(0.230)$ & $1.139^{\mathrm{b}}(0.089)$ \\
\hline $\begin{array}{l}\text { 23. Total esters as ethyl acetate, } \mathrm{g} / \mathrm{L} \\
\text { alcohol }\end{array}$ & $2.477^{\mathrm{a}}(0.057)$ & $2.19^{\mathrm{b}}(0.114)$ \\
\hline \multicolumn{3}{|l|}{$\begin{array}{l}\text { 24. Aldehydes as acetaldehyde, g/L } \\
\text { alc. }\end{array}$} \\
\hline a. Total & $0.601^{\mathrm{a}}(0.001)$ & $0.410^{\mathrm{b}}(0.010)$ \\
\hline b. Free & $0.523^{\mathrm{a}}(0.020)$ & $0.361^{\mathrm{b}}(0.019)$ \\
\hline c. Combined & $0.078^{\mathrm{a}}(0.019)$ & $0.048^{\mathrm{b}}(0.010)$ \\
\hline
\end{tabular}

* Values are the means of three determinations. Means followed by similar superscripts are not significantly different $(p>0.05)$. Figures in the parentheses are standard deviations. 